JAMP: Jurnal Adminitrasi dan Manajemen Pendidikan

Volume 2 Nomor 4 Desember 2019, Hal : 204-212

Tersedia Online di http://journal2.um.ac.id/index.php/jamp/

ISSN 2615-8574 (online)

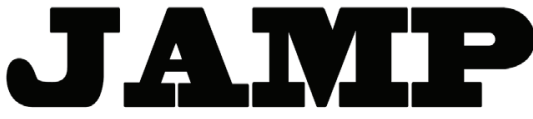

JURNAL ADMINISTRASI DAN MANAJEMEN PENDIDIKAN

\title{
MANAJEMEN PEMBINAAN KARAKTER PESERTA DIDIK DI SEKOLAH DASAR
}

\author{
Devita Fahrilyani \\ Maisyaroh \\ Desi Eri Kusumaningrum \\ Universitas Negeri Malang, Jl. Semarang No. 5 Malang 65145 \\ devitafahri@gmail.com
}

\begin{abstract}
This study aims to describe the character development planning of students, organizing character building of students, implementing character building for students, supporting factors and inhibiting the character building of students, participation of participants. This study uses qualitative and type of case study research. Data collection techniques in this study used interview, observation and documentation techniques. The results of this study are character building planning which begins with the implementation of the working meeting, organizing character coaching with the division of tasks, authorities and responsibilities of the parties involved, the implementation of character development is carried out by direct assistance and transfer, supporting factors in consultation activities and participation from students, teachers and employees, the level of trust of participants, and sponsors. The inhibiting factor is lazy students, the physical condition of students who are less healthy and increasingly busy. The solution given when conducting intense communication with presentations and activities that will be discussed will be carried out by students. Evaluation of student character development is carried out once a week in the teacher council meeting. The role of the principal as the culmination of policy, the principal is also the leader, responsible for activities as well as an innovator. The teacher also acts as a companion during the activity and as an example in implementing good roles.
\end{abstract}

Keywords: management, character building, students

Abstrak: Penelitian ini bertujuan untuk mendeskripsikan perencanaan pembinaan karakter peserta didik, pengorganisasian pembinaan karakter peserta didik, pelaksanaan pembinaan karakter peserta didik, faktor pendukung dan penghambat pembinaan karakter peserta didik, evaluasi pelaksanaan pembinaan karakter peserta didik, peran kepala sekolah dan guru dalam pelaksanaan pembinaan karakter peserta didik. Penelitian ini menggunakan pendekatan kualitatif dan jenis penelitian studi kasus. Teknik pengumpulan data dalam penelitian ini menggunakan teknik wawancara, observasi dan dokumentasi. Hasil dari penelitian ini adalah perencanaan pembinaan karakter diawali dengan pelaksanaan raker, pengorganisasian pembinaan karakter yakni dengan pembagian tugas, wewenang dan tanggung jawab dari pihak yang terlibat, pelaksanaan pembinaan karakter dilakukan dengan pendampingan dan pemantauan langsung, faktor pendukung dalam pelaksanaan kegiatan ialah partisipasi dan keikutsertaan dari peserta didik, guru dan karyawan, tingkat kepercayaan orangtua, dan sponsorship. Faktor penghambatnya yaitu peserta didik yang malas/lambat, kondisi fisik peserta didik yang kurang sehat dan orangtua yang terlalu sibuk. Solusi yang diberikan yakni melakukan komunikasi yang intens terhadap orangtua dan selalu mengingatkan kegiatankegiatan yang akan dilaksanakan oleh peserta didik. Evaluasi pembinaan karakter peserta didik dilaksanakan satu minggu sekali dalam rapat dewan guru. Peran kepala sekolah yakni sebagai puncak kebijakan, kepala sekolah juga sebagai pemimpin, penanggung jawab kegiatan sekaligus sebagai inovator. Guru juga berperan sebagai pendamping selama kegiatan berlangsung dan sebagai teladan dalam menerapkan perilaku yang baik.

Kata kunci: manajemen, pembinaan karakter, peserta didik 
Pendidikan merupakan usaha sadar yang dilakukan secara sistematis dalam mewujudkan suasana belajar mengajar bagi peserta didik untuk mengembangkan bakat dan potensinya serta untuk membentuk kepribadian yang baik dalam diri peserta didik. Pendidikan menurut Undang-Undang Nomor 20 tahun 2003 tentang Sistem Pendidikan Nasional (Sisdiknas) pasal 1 ayat 1 merupakan "usaha sadar dan terencana untuk mewujudkan suasana belajar dan proses pembelajaran agar peserta didik secara aktif mengembangkan potensi dirinya untuk memiliki kekuatan spiritual, keagamaan, pengendalian diri, kepribadian, kecerdasan, akhlak mulia, serta keterampilan yang diperlukan dirinya, masyarakat, bangsa dan negara". Pendidikan merupakan kebutuhan mutlak sebuah bangsa untuk menentukan kemajuan bangsa tersebut. Negara akan maju dan berkembang pesat apabila dilandasi dengan pendidikan. Dalam dunia pendidikan, diperlukan sebuah proses pembelajaran yang nantinya mampu membentuk karakter peserta didik. Menurut Hernawan (2008) "pembelajaran merupakan suatu kegiatan yang dilakukan melalui usaha-usaha yang terencana dalam proses pembentukan kepribadian siswa-siswi yang harusnya menjadi memiliki kepribadian yang berkarakter".

Pendidikan karakter bagi peserta didik adalah untuk membentuk kepribadian melalui pendidikan budi pekerti, seperti berperilaku yang baik, sopan, santun, jujur, bertanggung jawab, menghargai orang lain, dan sebagainya. Imron (2012) mengemukakan beberapa kode etik peserta didik yakni standar tingkah laku peserta didik yang layak ditampilkan, baik ketika berada di sekolah, di lingkungan keluarga, maupun di masyarakat, kapan peserta didik harus sudah berada di sekolah dan kapan juga peserta didik sudah berada di rumah kembali, bagaimana hubungan antara peserta didik dengan guru, kepala sekolah, personalia yang lain, dengan teman sebaya, orangtua, masyarakat pada umum bahkan tamu yang sedang berkunjung ke sekolah, dan apa yang dilakukan oleh peserta didik ketika ada diantara teman-teman yang merasa kesusahan. Samani dan Hariyanto (2013) berpendapat bahwa "di Indonesia, pelaksanaan pendidikan karakter saat ini memang dirasakan mendesak". Hal tersebut dapat dilihat dari semakin maraknya pergaulan bebas, tawuran antar pelajar, rendahnya moral pada anak, pemerasan/ kekerasan (bullying), kecenderungan dominasi senior terhadap junior, penggunaan narkoba, dan bentukbentuk kenakalan yang lain. Hermino (2013) juga mengemukakan beberapa penelitian yang dilakukan oleh para peneliti sebelumnya (Misco, 2007; Chattopadhay, 2013; Holgado, dkk, 2013; Wagner, 2013) mengemukakan bahwa "pendidikan karakter sangat penting diberikan kepada anak-anak di sekolah, hal ini agar anak-anak mengerti akan pentingnya nilai-nilai moral kemanusiaan dan dapat menghormati terhadap situasi dan kondisi lingkungannya". Dalam hal pendidikan karakter, kota Malang merupakan sebuah kota dimana masyarakatnya berasal dari berbagai daerah yang datang bertujuan untuk mengenyam pendidikan. Banyaknya masyarakat yang ingin mengenyam pendidikan di kota Malang tidak menutup kemungkinan masyarakat terutama peserta didik sekolah dasar di kota Malang memiliki berbagai perbedaan dari daerah mereka masing-masing. Oleh karena itu, tiap-tiap sekolah dasar di kota Malang sudah seharusnya menanamkan nilai-nilai yang baik untuk membentuk karakter diri peserta didik agar memiliki moral yang baik.

Pendidikan karakter ini sangat diperlukan terutama di sekolah dasar di kota Malang, melihat maraknya pergaulan bebas dan kenakalan-kenakalan remaja sudah banyak terjadi. Salah satu sekolah dasar di kota Malang yang telah menanamkan pendidikan karakter terhadap peserta didiknya adalah Sekolah Dasar (SD) Insan Amanah Malang. Sekolah ini pernah mendapatkan predikat sebagai sekolah berkarakter tahun 2018. SD Insan Amanah Malang memiliki berbagai kegiatan atau program-program yang mampu membentuk karakter atau kepribadian yang baik bagi peserta didik. Kegiatan-kegiatan tersebut dinaungi oleh tiga wakil kepala sekolah dan dibagi menjadi beberapa program. Programprogram tersebut meliputi program kurikulum, kesiswaan, dan keislaman. Program-program kurikulum sudah terintegrasi ke dalam pembelajaran sehari-hari. Program-program kesiswaan dan keislaman yang ada di SD Insan Amanah Malang yakni pendidikan anti bullying, pendidikan kecakapan hidup/life skill, Pendidikan Agama Islam khas SD Insan Amanah Malang yang meliputi bahasa arab, turjuman, fiqih, bina sholat. Kegiatan yang termasuk ke dalam non pembelajaran antara lain 3S (senyum, sapa, salam), gesit (gerakan siram tanaman), gemilang (gerakan melihat, ambil, buang), gemas (gerakan makan sehat), tilik desa, tilik panti, ZIS (Zakat, Infaq, Shodaqoh), immersion program dan studi ekskursi. 


\section{METODE}

Peneliti menggunakan pendekatan kualitatif dengan jenis penelitian studi kasus. Lokasi penelitian di SD Insan Amanah Malang Perumahan Griya Shanta Blok M Jalan Soekarno-Hatta, Mojolangu, Kecamatan Lowokwaru Kota Malang. Sumber data yang digunakan peneliti yakni waka akademik, waka keislaman, dan waka kesiswaan. Tiga teknik yang digunakan oleh peneliti dalam mengumpulkan data penelitian ialah dengan melakukan wawancara, observasi, dan dokumentasi. Peneliti telah menyusun pertanyaan sebagai panduan awal wawancara. Observasi dilakukan pada saat kegiatan sholat dhuha berjamaah, sholat dhuhur berjamaah, pendidikan kecakapan hidup/life skill, dan kegiatan GeMaS (Gerakan Makan Sehat). Data hasil pengamatan didokumentasikan pada catatan lapangan. Dokumentasi dilakukan menggunakan smartphone. Peneliti juga mendapatkan dokumentasi pelengkap dari sekolah berupa profil sekolah dan foto kegiatan pembinaan. Pada analisis data, peneliti mengumpulkan data terlebih dahulu, kemudian direduksi dengan memberi kode fokus pada transkrip wawancara, memaparkan data berdasarkan fokus penelitian, dan membuat kesimpulan dari temuan penelitian. Pengecekan keabsahan data dalam penelitian ini menggunakan triangulasi sumber dan teknik, member check dan kecukupan bahan referensi.

\section{HASIL}

\section{Perencanaan Pembinaan Karakter Peserta Didik di SD Insan Amanah Malang}

Perencanaan pembinaan karakter peserta didik di SD Insan Amanah Malang tidak dilaksanakan secara serta merta. Artinya, sekolah memiliki kegiatan terstruktur dalam pembinaan karakter peserta didik. Perencanaan pembinaan karakter peserta didik di SD Insan Amanah Malang ialah dengan melaksanakan rapat kerja atau yang biasa disebut dengan raker. Dalam rapat kerja, kegiatan awal yang dilakukan ialah mengadakan evaluasi kegiatan di sekolah selama satu tahun kemarin. Kegiatan ini biasa disebut dengan pra raker. Rapat kerja di SD Insan Amanah Malang dilaksanakan satu tahun sekali dan diikuti oleh bapak ibu guru dan karyawan sekolah. Wakil kepala sekolah urusan akademik, kesiswaan dan keislaman masing-masing memiliki program. Mereka membuat konsep dasar terlebih dahulu sesuai dengan evaluasi program tahun lalu, kemudian di koordinasikan dengan bapak ibu guru dan karyawan sekolah yang sudah di bagi dalam 5 komisi dalam rapat kerja guru. Komisi tersebut yakni komisi bagian sarana prasarana, pengajaran, kurikuler, kesiswaan dan keislaman. Setelah konsep dasar tersebut selesai dibuat, akan digabungkan menjadi satu program dan dibawa ke lembaga, didiskusikan dan segera diresmikan sebagai acuan program untuk satu tahun ke depan.

Adapun dua aspek yang terdapat dalam kegiatan pembinaan karakter peserta didik di SD Insan Amanah Malang yakni aspek spiritual dan aspek sosial. Kegiatan dalam pembinaan karakter ini dibagi dalam kegiatan pembelajaran dan non pembelajaran. Dalam program kesiswaan, kegiatan yang termasuk dalam pembelajaran sudah terintegrasi di pembelajaran reguler sesuai dengan RPP. Kegiatan non pembelajaran meliputi 3S (senyum, sapa, salam), gesit (gerakan siram tanaman), gemilang (gerakan lihat, ambil, buang), pendidikan anti bullying. Program-program pembinaan karakter yang termasuk ke dalam program keislaman yaitu pembelajaran Alqur'an, PAI khas SD Insan Amanah Malang. Programprogram keislaman lain yang termasuk ke dalam kegiatan non pembelajaran antara lain memberikan santunan ke dhuafa yang biasa disebut ZIS (Zakat, Infaq, Shodaqoh).

SD Insan Amanah Malang juga memiliki program tilik desa dan tilik panti asuhan. Kegiatan tersebut dilaksanakan untuk memperkuat kepekaan peserta didik terhadap lingkungan di sekitarnya, karena peserta didik rata-rata berasal dari keluarga ekonomi menengah ke atas. Dari kegiatan ini, peserta didik dapat merasakan apa yang selama ini tidak pernah didapatkan dari lingkungan di sekitar rumahnya. SD Insan Amanah Malang juga memiliki program unggulan yakni immersion program dan studi ekskursi, dimana dalam hal ini peserta didik melakukan kunjungan belajar ke luar negeri (Singapura, Australia, dan Malaysia). Program ini dapat mengajarkan karakter kepada pesera didik, seperti ketika mereka jauh dari orangtua, dibiasakan untuk mandiri, tanggung jawab dan pembiasaan-pembiasaan baik yang sudah diajarkan di sekolah diterapkan di sana. Karena tradisi dan budaya di luar negeri sudah pasti berbeda, 
peserta didik juga diajarkan cara menghargai budaya di sana dan tetap menjaga sopan santunnya. Immersion program berbeda dengan studi ekskursi. Immersion program merupakan program kunjungan belajar ke luar negeri selama beberapa hari, sedangkan studi ekskursi merupakan kunjungan belajar yang dilaksanakan hanya satu hari.

\section{Pengorganisasian Pembinaan Karakter Peserta Didik di SD Insan Amanah Malang}

Kepala sekolah SD Insan Amanah Malang melakukan pembagian tugas atau pengorganisasian kepada guru-guru dalam kegiatan pembinaan karakter peserta didik. Dalam pengorganisasian pembinaan karakter peserta didik, panitia sudah disusun dari awal. Penanggung jawab dalam kegiatan ini ialah kepala sekolah yang dibawahi oleh 3 wakil kepala sekolah yaitu wakil kepala sekolah urusan akademik, wakil kepala sekolah bagian kesiswaan dan wakil kepala sekolah bagian keislaman. Wakil kepala sekolah urusan akademik di bawahi oleh 2 penanggung jawab yakni penanggung jawab PSB dan IT yang kemudian dibawahnya ada 20 wali kelas dan semua guru, Tugas PSB ialah untuk membantu guru-guru dalam menyediakan media pembelajaran yang menarik bagi peserta didik, karena terkadang ada guru yang kurang menguasai ilmu pengetahuan dan teknologi (IPTEK). Sedangkan IT hanya fokus untuk pengolahan nilai. Sedangkan wakil kepala sekolah bagian kesiswaan dan humas di bawahi oleh penanggung jawab kesiswaan dan ekstrakurikuler, kemudian di bawahnya ada koordinator UKS dan BK.

\section{Pelaksanaan Pembinaan Karakter Peserta Didik di SD Insan Amanah Malang}

Pelaksanaan pembinaan karakter peserta didik merupakan salah satu bagian dari implementasi pendidikan karakter yang telah disusun dan direncanakan sebelumnya. Pendidikan karakter ditujukan untuk membangun dan membentuk karakter peserta didik. Peserta didik di SD Insan Amanah Malang melaksanakan kegiatan pembinaan karakter melalui beberapa kegiatan yang dapat menanamkan nilai spiritual dan nilai sosial kepada mereka. Kegiatan yang mencakup ke dalam pembelajaran ialah pendidikan anti bullying, pendidikan kecakapan hidup/life skill, Pendidikan Agama Islam khas SD Insan Amanah Malang yang meliputi bahasa arab, turjuman, fiqih, bina sholat. Kegiatan yang termasuk ke dalam non pembelajaran antara lain $3 \mathrm{~S}$ (senyum, sapa, salam), gesit (gerakan siram tanaman), gemilang (gerakan melihat, ambil, buang), gemas (gerakan makan sehat), tilik desa, tilik panti, ZIS (Zakat, Infaq, Shodaqoh), immersion program dan studi ekskursi.

Sebelum pelaksanaan pembinaan karakter dimulai, pihak sekolah terlebih dahulu melakukan sosialisasi kepada seluruh warga sekolah serta wali murid mengenai program-program yang akan dilaksanakan. Program-program pembinaan karakter di SD Insan Amanah Malang terintegrasi ke dalam pembelajaran. Program-program tersebut juga dilaksanakan di sekolah dan ada yang dilaksanakan di luar sekolah. Seperti dalam kegiatan kesiswaan, kegiatan tersebut tentu dilaksanakan di sekolah, misalnya pendidikan kecakapan hidup/life skill, gemilang (gerakan melihat, ambil, buang), gesit (gerakan siram tanaman), dan gemas (gerakan makan sehat). Namun, dalam kesiswaan juga terdapat tugas mandiri bagi peserta didik yang dilalakukan di rumah. Pendidikan kecakapan hidup/life skill di SD Insan Amanah Malang dilaksanakan satu bulan sekali.

SD Insan Amanah Malang juga melaksanakan kegiatan bina sholat bagi peserta didik. Bina sholat ini dimaksudkan agar peserta didik dapat melakukan wudhu dan sholat dengan benar. Ketika peserta didik wudhu, pembina sholat selalu mendampingi, dan apabila ada peserta didik yang wudhunya tidak sempurna akan ditegur dan diajarkan bagaimana wudhu yang benar. Kegiatan sholat dhuhur berjamaah dilakukan setiap hari bagi peserta didik kelas 6 dan digilir bagi kelas 1 sampai kelas 5. SD Insan Amanah Malang juga memiliki Buku Bina Mandiri (BBM) untuk mengontrol kegiatan sholat peserta didik. Buku Bina Mandiri tersebut juga bisa dijadikan sebagai tolak ukur guru-guru setelah terlaksananya kegiatan. Kegiatan pembinaan karakter lainnya yang diterapkan di SD Insan Amanah Malang ialah pendidikan anti perundungan/anti bullying. Kegiatan ini terintegrasi ke dalam pembelajaran. Program-program sosial lainnya yang diselenggarakan oleh SD Insan Amanah Malang antara lain tilik desa, tilik panti 
asuhan dan ZIS (Zakat, Infaq, Sodaqoh). Dalam kegiatan tilik desa, peserta didik tinggal di rumah warga selama 2 hari 1 malam. Selain tilik desa, ada juga kegiatan tilik panti asuhan. Kegiatan ini bertujuan agar peserta didik senantiasa bersyukur dengan apa yang dimiliki sekarang. Kegiatan ZIS (Zakat, Infaq, Sodaqoh) merupakan kegiatan santunan yang dilaksanakan di sekolah pada bulan ramadhan dengan mengundang dhuafa dan membagikan sembako bagi para dhuafa.

\section{Faktor Pendukung dan Penghambat dalam Pelaksanaan Pembinaan Karakter Peserta Didik di SD Insan Amanah Malang}

Pelaksanaan suatu program kegiatan selalu terdapat faktor pendukung dan penghambat. Faktor pendukung utama dalam kegiatan pembinaan karakter peserta didik di SD Insan Amanah Malang yakni semua komponen sekolah yang meliputi peserta didik, semua guru dan karyawan, orang tua, dan pihak luar (sponsorship) yang terlibat dalam pelaksanaan kegiatan. Faktor pendukung dari orangtua yakni berupa tingkat kepercayaan orangtua yang luar biasa kepada sekolah. Selain faktor pendukung juga terdapat faktor penghambat dalam pelaksanaan. Faktor penghambat tersebut antara lain yaitu berasal dari peserta didik itu sendiri dan juga orangtua yang terlambat mengantarkan peserta didik ke sekolah jika ada kegiatan pagi di sekolah. Faktor lain dari orangtua yaitu kadang orangtua tidak memiliki banyak waktu atau terlalu sibuk sehingga peserta didik kurang kontrol di rumah. Adapun solusi yang dapat diberikan oleh pihak sekolah yakni dengan melakukan komunikasi yang intens terhadap orangtua dan selalu mengingatkan kegiatan-kegiatan yang akan dilaksanakan oleh peserta didik.

\section{Evaluasi Pelaksanaan Pembinaan Karakter Peserta Didik di SD Insan Amanah Malang}

Evaluasi merupakan tahap akhir yang dilakukan setelah pelaksanaan kegiatan. Evaluasi di SD Insan Amanah Malang dilaksanakan setiap satu minggu sekali yakni hari Jum'at atau Sabtu dalam rapat dewan guru. Rapat tersebut dilakukan untuk mengevaluasi kegiatan selama satu minggu. Selama evaluasi berlangsung, hal tersebut tentunya tidak lepas dari adanya faktor penunjang dan terdapat hal-hal yang menghambat berlangsungnya kegiatan evaluasi. Faktor utama yang mendukung kegiatan evaluasi yaitu guru-guru yang saling terbuka satu sama lain untuk menyuarakan kekurangan-kekurangan yang ada pada saat pelaksanaan kegiatan. Kekurangan-kekurangan tersebut yang nantinya akan dijadikan bahan evaluasi agar pelaksanaan kegiatan-kegiatan berikutnya dapat berjalan sesuai yang diharapkan. Kegiatan evaluasi dalam rapat dewan guru dilaksanakan tanpa ada hambatan karena semua pihak sekolah sudah berkomitmen bahwa evaluasi dilakukan untuk menjadikan kegitaan-kegiatan selanjutnya menjadi lebih baik lagi.

\section{Peran Kepala Sekolah dan Guru dalam Pelaksanaan Pembinaan Karakter Peserta Didik di SD Insan Amanah Malang}

Pelaksanaan pembinaan karakter peserta didik di SD Insan Amanah Malang tidak lepas dari peran kepala sekolah dan guru. Kepala sekolah memegang peranan penting dalam pelaksanaan pembinaan karakter. Kepala sekolah memiliki peran yang besar dalam program-program yang dilaksanakan oleh sekolah, karena kepala sekolah sebagai pemimpin pelaksanaan kegiatan. Kepala sekolah juga memiliki peran sebagai penanggung jawab dan yang mengontrol persiapan sebelum pelaksanaan. Selain kepala sekolah, guru-guru juga ikut berperan dalam pelaksanaan pembinaan karakter peserta didik. Guru-guru di SD Insan Amanah Malang sebagai ujung tombak dalam pelaksanaan, karena guru-guru berhadapan langsung dengan peserta didik. Sebelum mengimplementasikan kepada peserta didik, guru-guru terlebih dahulu memberikan teladan kepada peserta didik atau menerapkan hal-hal baik kepada sesama guru sebelum mengajarkan kepada peserta didik. 


\section{PEMBAHASAN}

\section{Perencanaan Pembinaan Karakter Peserta Didik di SD Insan Amanah Malang}

Proses perencanaan pembinaan karakter peserta didik yakni dengan pelaksanaan rapat kerja atau yang biasa disebut dengan raker. Tim Pakar Manajemen Pendidikan Universitas Negeri Malang (2004) mengatakan bahwa "di era otonomi daerah, desentralisasi pengelolaan pendidikan dan school based management seperti sekarang, manajer pendidikan harus bahu-membahu dengan komite sekolah dan stake holders guna merumuskan pendidikan di sekolah". Hal ini sesuai dengan temuan di lapangan bahwa rapat kerja dipimpin langsung oleh kepala sekolah yang dibantu oleh waka akademik, kesiswaan, dan keislaman serta melibatkan semua guru. Langkah awal sebelum pelaksanaan raker ialah dengan mengadakan pra raker yang dilaksanakan oleh pimpinan dan waka untuk mengevaluasi program tahun lalu. Hal ini didukung dengan pernyataan Purwanto (2008) bahwa dalam melakukan perencanaan terdapat beberapa langkah yang harus dilakukan yaitu menentukan dan merumuskan tujuan yang hendak dicapai, meneliti masalah-masalah yang akan dilakukan, mengumpulkan data dan informasi yang diperlukan, serta merumuskan bagaimana masalah-masalah itu akan dipecahkan.

Mulyono (2010) menyatakan bahwa perencanaan merupakan rencana memiliki pedoman untuk memperoleh dan menggunakan sumber daya yang diperlukan untuk mencapai tujuan, melaksanakan aktivitas, dan emonitor serta mengukur kemajuan untuk mencapai tujuan sehingga tindakan korektif dapat diambil bila kemajuan tidak memuaskan. Sesuai dengan temuan penelitian, bahwa SD Insan Amanah Malang dalam melaksanakan pra-raker melibatkan beberapa pihak yakni waka akademik, kesiswaan, dan keislaman untuk menyusun program baru berdasarkan evaluasi program tahun lalu. SD Insan Amanah Malang membuat strategi dengan mencetak buku panduan pendidikan yang dibagikan kepada seluruh warga sekolah sebagai acuan satu tahun ke depan. Hal ini sesuai dengan pendapat Gunawan dan Benty (2017) mengenai pengertian perencanaan ialah proses mendefinisikan tujuan organisasi, membuat strategi untuk mencapai tujuan itu dan mengembangkan rencana aktivitas kerja organisasi.

\section{Pengorganisasian Pembinaan Karakter Peserta Didik di SD Insan Amanah Malang}

Lembaga membutuhkan suatu organisasi agar lebih terkoordinasikan dengan baik. Pengorganisasian sangat penting dilakukan untuk memperjelas tugas, wewenang dan tanggung jawab dari pihak-pihak yang terlibat dalam kegiatan pembinaan karakter peserta didik. Hal ini sesuai dengan fungsi organisasi menurut Mulyono (2010) ialah menetapkan bidang-bidang kerja, metode dan alat yang dibutuhkan, serta personal yang dibutuhkan dan membina hubungan antara personal yang terlibat, tanggung jawab, wewenang, hak dan kewajiban mereka sehingga mempercepat tercapainya tujuan organisasi. Pengorganisasian menurut Gunawan dan Benty (2017) merupakan proses menetapkan secara rapi menggunakan sumber daya dengan menugaskan dan mengkoordinasikan tugas. Pendapat ini sesuai dengan keadaan di lapangan bahwa pimpinan sekolah yakni kepala sekolah membagi tugas-tugas kepada bawahannya dengan cara menyusunnya ke dalam struktur kepengurusan rapat kerja. Dengan adanya struktur tersebut, maka bawahannya yang tidak lain adalah bapak/ibu guru dan karyawan sekolah dapat mengetahui dan memahami tugas-tugas yang harus mereka laksanakan selama kegiatan pembinaan karakter berlangsung.

\section{Pelaksanaan Pembinaan Karakter Peserta Didik di SD Insan Amanah Malang}

Pelaksanaan pembinaan karakter peserta didik merupakan salah satu bagian dari implementasi pendidikan karakter yang telah disusun dan direncanakan sebelumnya. Hal ini sesuai dengan fungsi penggerakan menurut Amtu (2013) merupakan gerak pelaksanaan dari kegiatan-kegiatan perencanaan dan pengorganisasian. Berdasarkan pada paparan data, program-program pembinaan karakter di SD Insan Amanah Malang terintegrasi ke dalam pembelajaran. Program-program tersebut juga dilaksanakan di sekolah dan ada yang dilaksanakan di luar sekolah. Hasil penelitian sesuai dengan pendapat Terry 
(dalam Riduwan, 2009) bahwa penerapan pendidikan di sekolah dapat ditempuh melalui empat alternatif strategi secara terpadu, salah satunya yaitu dengan mengintegrasikan konten pendidikan karakter ke dalam seluruh mata pelajaran. Kedua, mengintegrasikan pendidikan karakter ke dalam kegiatan seharihari di sekolah. Kegiatan sehari-hari tersebut yang pertama yaitu menerapkan keteladanan. Pembiasaan keteladanan adalah kegiatan dalam bentuk perilaku sehari-hari yang tidak diprogramkan karena dilakukan tanpa mengenal batasan ruang dan waktu. Keteladanan ini merupakan perilaku dan sikap guru, tenaga pendidikan dan peserta didik dalam memberikan contoh melalui tindakan-tindakan yang baik sehingga diharapkan menjadi panutan bagi peserta didik lain. Hal ini sesuai dengan keadaan di lapangan, bahwa pendidikan karakter di SD Insan Amanah Malang diintegrasikan dalam pembelajaran sehari-hari. Karakter akan terbentuk karena adanya pembiasaan dalam melakukan kegiatan. Hal tersebut yang selalu diterapkan oleh bapak dan ibu guru di sekolah. Bapak dan ibu guru juga menjadi teladan di sekolah dalam melakukan kebiasaan-kebiasaan baik, karena dengan demikian peserta didik akan menirukan kebiasaan baik tersebut. Sependapat dengan Imron (2012) bahwa disiplin harus ditanamkan terus-menerus kepada peserta didik karena jika disiplin ditanamkan secara terus-menerus maka disiplin akan menjadi kebiasaan bagi peserta didik.

Konsep pendidikan menurut Almerico (2014) diajarkan dalam konteks sastra, siswa menyadari sifat-sifat seperti rasa hormat, kejujuran, keberanian, dan kebaikan, hal tersebut disesuaikan dengan keadaan nyata di sekolah. Sesuai dengan temuan peneliti, sekolah sering mengadakan program-program yang bersifat kebaikan yakni tilik panti asuhan dan ZIS. Program tilik panti asuhan dapat membentuk kepedulian peserta didik terhadap anak-anak panti asuhan yang tidak memiliki orangtua. Begitu juga dengan ZIS, peserta didik memberikan santunan kepada dhuafa yang dilaksanakan di sekolah pada bulan ramadhan.

SD Insan Amanah Malang juga melakukan komunikasi intens dengan orangtua peserta didik. Pihak sekolah selalu memberikan informasi mengenai kegiatan-kegiatan peserta didik selama di sekolah dan juga selalu mengingatkan orangtua peserta mengenai program atau kegiatan-kegiatan yang akan dilaksanakan. Hal ini sesuai dengan pendapat Terry (dalam Riduwan, 2009) bahwa dalam konsep lingkungan pendidikan, maka perlu mengenal tiga macam lingkungan yang dialami oleh peserta didik dalam masa yang bersamaan, antara lain: lingkungan keluarga, sekolahan dan masyarakat sekitarnya. Oleh karena itu, sekolah perlu mengkomunikasikan segala kebijakan dan pembiasaan yang dilakukan di sekolah kepada orangtua/wali murid dan masyarakat sekitar, sehingga program pendidikan karakter tidak hanya terlaksana di sekolah dan menjadi tanggung jawab satu-satunya. Dengan kerja sama yang baik antara lingkungan tersebut, maka akan berpengaruh terhadap pertumbuhan dan perkembangan karakter peserta didik yang lebih terkontrol.

\section{Faktor Pendukung dan Penghambat dalam Pelaksanaan Pembinaan Karakter Peserta Didik di SD Insan Amanah Malang}

Faktor pendukung dalam pelaksanaan pembinaan karakter peserta didik di SD Insan Amanah Malang yaitu semua komponen sekolah yang meliputi peserta didik, semua guru dan karyawan, orang tua, dan pihak luar yang terlibat dalam pelaksanaan kegiatan. Pihak luar yang terlibat yakni meliputi orang-orang yang bersedia untuk membantu kelengkapan sarana prasarana dalam pelaksanaan kegiatan. Faktor pendukung sangat penting untuk menunjang keberhasilan pelaksanaan kegiatan, terutama pemenuhan sarana prasarana. Faktor pentingnya terpenuhi sarana ini dijelaskan dalam Ubaidah (2012) yang menjelaskan bahwa sarana pendidikan terbagi menjadi alat pelajaran, alat peraga dan media pembelajaran. Sarana dan prasarana merupakan salah satu faktor yang penting dalam penyelenggaraan kegiatan pembinaan karakter, karena apabila sarana prasarana yang digunakan kurang mendukung, maka pelaksanaan kegiatan tidak bisa berjalan secara maksimal. Adapun faktor penghambatnya antara lain terkadang ada peserta didik yang malas/lelet, faktor fisik peserta didik yang kurang sehat, orangtua yang tidak memiliki banyak waktu dan yang terlambat mengantarkan ke sekolah apabila ada kegiatan di sekolah. Adapun solusi yang dapat diberikan oleh pihak sekolah yakni dengan melakukan komunikasi yang intens terhadap orangtua dan selalu mengingatkan kegiatan-kegiatan yang akan dilaksanakan oleh peserta didik. 


\section{Evaluasi Pelaksanaan Pembinaan Karakter Peserta Didik di SD Insan Amanah Malang}

Evaluasi di SD Insan Amanah Malang dilaksanakan setiap satu minggu sekali yakni hari Jum'at atau Sabtu dalam rapat dewan guru. Rapat tersebut dilakukan untuk mengevaluasi kegiatan selama satu minggu. Kegiatan dalam evaluasi tersebut ialah mereview kegiatan yang telah dilaksanakan selama satu minggu, kekurangan dan kendala apa saja yang terjadi selama kegiatan berlangsung. Apabila terdapat kekurangan, maka sekolah akan melakukan perbaikan untuk kegiatan selanjutnya. Seperti pendapat Kurniadin dan Machali (2012) evaluasi adalah suatu proses yang sistematis dan berkelanjutan guna menentukan kualitas (nilai dan arti) daripada sesuatu berdasarkan atas pertimbangan dan kriteria tertentu dalam rangka mengambil keputusan. Fattah (2009) mengatakan bahwa tujuan evaluasi ialah memperoleh dasar pertimbangan akhir periode kerja, apa yang telah dicapai, dan yang perlu mendapatkan perhatian khusus, menjamin cara kerja yang efektif dan efisien, memperoleh fakta tentang kesulitan yang dialami, hambatan, dan penyimpangan yang dilihat dari aspek tertentu. Hal tersebut sesuai dengan fakta di lapangan bahwa pada saat evaluasi dilaksanakan, guru-guru menyuarakan kekurangan-kekurangan yang ada pada saat pelaksanaan kegiatan. Kekurangan-kekurangan tersebut yang nantinya akan dijadikan bahan evaluasi agar pelaksanaan kegiatan-kegiatan berikutnya dapat berjalan lebih baik lagi.

\section{Peran Kepala Sekolah dan Guru dalam Pelaksanaan Pembinaan Karakter Peserta Didik di SD Insan Amanah Malang}

Pelaksanaan pembinaan karakter peserta didik di SD Insan Amanah Malang tidak lepas dari peran kepala sekolah dan guru. Kepala sekolah memegang peranan penting dalam pelaksanaan pembinaan karakter. Peran kepala sekolah menurut Sarros dan Cooper (2006) menjelaskan bahwa seorang pemimpin dalam proses pembentukan karakter bertanggungjawab secara sosial dan praktik dalam pelaksanaannya serta tidak dapat diremehkan perannya. Senada dengan temuan peneliti bahwa kepala sekolah memiliki peran yang besar dalam program-program yang berjalan, karena kepala sekolah sebagai pemimpin pelaksanaan kegiatan. Kepala sekolah dalam hal ini juga sebagai innovator sekaligus penanggung jawab selama kegiatan berlangsung. Kepala sekolah juga yang mengontrol persiapan sebelum pelaksanaan.

Guru-guru juga ikut berperan dalam pelaksanaan pembinaan karakter peserta didik. Peran guru ketika proses pembelajaran dalam program pendidikan karakter menurut Marini (2017) terdapat beberapa integrasi kegiatan seperti kehadiran guru yang tepat waktu, siswa berdo'a sebelum belajar, inspeksi guru tentang kerapian dan kehadiran siswa, tata karma atau perilaku guru, guru menjadi model atau teladan siswa dalam kegiatan yang ada di dalam kelas, guru dan siswa bersama memberi salam sebelum proses pembelajaran, rencana pelajaran yang mengandung nilai karakter, dan interaksi antara guru dan siswa di dalam maupun di luar kelas. Sesuai dengan temuan peneliti yakni guru-guru di SD Insan Amanah Malang berperan sebagai teladan bagi peserta didik, karena guru-guru berhadapan langsung dengan peserta didik. Guru-guru terlebih dahulu memberikan contoh dengan menerapkan hal-hal baik kepada sesama guru sebelum mengajarkan kepada peserta didik.

\section{SIMPULAN DAN SARAN}

Perencanaan pembinaan karakter peserta didik di SD Insan Amanah Malang diawali dengan pelaksanaan rapat kerja atau yang biasa disebut dengan raker. Namun, sebelum raker dilaksanakan, ada pra-raker yang gunanya yaitu untuk melakukan evaluasi mengenai program kegiatan yang telah berjalan satu tahun kemarin. Pengorganisasian pembinaan karakter peserta didik di SD Insan Amanah Malang yakni dengan pembagian tugas, wewenang dan tanggung jawab dari pihak-pihak yang terlibat dalam kegiatan pembinaan karakter peserta didik. Pelaksanaan pembinaan karakter peserta didik di SD Insan Amanah Malang ini dilakukan dengan pendampingan dan pemantauan langsung terhadap pelaksanaan kegiatan. Pendampingan dan pemantauan dilakukan dengan maksud agar peserta didik dapat melaksanakan kegiatan dengan benar dan tepat.

Faktor yang mendukung dalam pelaksanaan pembinaan karakter peserta didik di SD Insan Amanah 
Malang ialah partisipasi dan keikutsertaan dari peserta didik, sumber daya yang dimiliki sekolah yaitu semua guru dan karyawan, tingkat kepercayaan orangtua yang tinggi, dan juga pihak luar (sponsorship) yang terlibat dalam kegiatan. Adapun faktor yang menghambat yaitu peserta didik yang malas/lambat, kondisi fisik peserta didik yang kurang sehat dan orangtua yang tidak memiliki banyak waktu luang. Solusi yang diberikan oleh pihak sekolah yakni dengan melakukan komunikasi yang intens terhadap orangtua dan selalu mengingatkan kegiatan-kegiatan yang akan dilaksanakan oleh peserta didik. Evaluasi pembinaan karakter peserta didik di SD Insan Amanah Malang dilaksanakan satu minggu sekali setiap hari Jum'at dalam rapat dewan guru untuk mengevaluasi kegiatan harian selama satu minggu. Adapun faktor yang mendukung berjalannya kegiatan evaluasi ialah keterbukaan guru-guru untuk menyuarakan kekurangan-kekurangan yang ada pada saat pelaksanaan kegiatan. Kepala sekolah memiliki peran yang besar dalam pelaksanaan pembinaan karakter peserta didik di SD Insan Amanah Malang. Selain sebagai puncak kebijakan, kepala sekolah juga sebagai pemimpin, penanggung jawab kegiatan sekaligus sebagai inovator. Guru-guru dalam hal ini juga memiliki peran sebagai pendamping selama kegiatan berlangsung dan sebagai objek dalam memberikan teladan kepada peserta didik untuk menerapkan hal-hal baik kepada sesama guru sebelum mengajarkan kepada peserta didik.

Berdasarkan simpulan diatas, disarankan kepada peneliti lain apabila melakukan penelitian sejenis diharapkan dapat mengikuti pelaksanaan evaluasi mingguan yang dilaksanakan dalam rapat dewan guru.

\section{DAFTAR RUJUKAN}

Fattah, N. 2009. Landasan Manajemen Pendidikan. Bandung: PT Remaja Rosdakarya.

Gunawan, I. dan Benty, D. D. N. 2017. Manajemen Pendidikan: Suatu Pengantar Praktik. Bandung: Alfabeta.

Hermino, A. 2013. Pendidikan Karakter dalam Perspektif Psikologis Siswa Menengah Pertama di Era Globalisasi dan Multikultural. Jurnal Administrasi Pendidikan, (Online), No. 2, Vol. 24, (http://ap.fip.um.ac.id/wpcontent/uploads/2015/05/volume-24-no.-223-33.pdf), diakses 9 April 2018.

Hernawan, H. 2008. Pengembangan Kurikulum Pembelajaran. Jakarta: Universitas Terbuka.

Imron, A. 2012. Manajemen Peserta Didik Berbasis Sekolah. Jakarta: Bumi Aksara.

Kurniadin, D. \& Machali, I. 2012. Manajemen Pendidikan: Konsep \& Prinsip Pengelolaan Pendidikan. Jogjakarta: Ar-Ruzz Media.

Marini, A. 2017. Character Building Through Teaching Learning Process: Lesson in Indonesia: International Journal of Sciences and Reseacrh, 73 (5) 177-182. Dari https://www.researchgate.net/publication/317649293 CHARACTER_BUILDING_THROUGH_TEACHING_LEARNING_PROCESS_LESSON_IN_INDONESIA/download.

Mulyono, M. A. 2010. Manajemen Administrasi dan Organisasi Pendidikan. Jogjakarta: Ar-Ruzz Media.

Purwanto, N. 2008. Dasar-dasar Ilmu Pendidikan. Yogyakarta: Ar-Ruzz Media.

Riduwan. 2009. Manajemen Pendidikan. Bandung: Alfabeta.

Samani, M. dan Hariyanto. 2013. Konsep dan Model Pendidikan Karakter. Bandung: PT Remaja Rosdakarya Offset.

Sarros, J.C., dan Cooper, B.K. 2006. Building Character: A Leadership Essesntial: Journal of Business and Psychology, 21 (1) 1-22. Dari libgen.io/scimag/get.php?doi=10.1007/s10869-005-9020-3.

Tim Pakar Manajemen Pendidikan Universitas Negeri Malang. 2002. Manajemen Pendidikan Wacana, Proses, dan Aplikasinya di Sekolah. Malang: Universitas Negeri Malang.

Ubaidah, S. 2012. Manajemen Ekstrakuriruler dalam Meningkatkan Mutu Sekolah. (Online), (https://media.neliti. com/media/publications/56738-ID-manajemen-ekstrakurikuler-dalam-meningka.pdf), diakses 18 Juni 2019.

Undang-Undang Republik Indonesia Nomor 20 Tahun 2003 tentang Sistem Pendidikan Nasional. 2014. Bandung: Citra Umbara. 